\author{
D.D. Seitov ${ }^{1,3}$, K.A. Nekrasov ${ }^{1}$, A.Ya. Kupryazhkin ${ }^{1}$, S.K. Gupta ${ }^{2}$, A.T. Akilbekov ${ }^{3}$ \\ ${ }^{1}$ B.N. Yeltsin Ural Federal University, Yekaterinburg, Russia; \\ ${ }^{2}$ St. Xavier's College, Ahmedabad, India; \\ ${ }^{3}$ L.N. Gumilyov Eurasian National University, Astana, Kazakhstan \\ (E-mail:seitov1992@mail.ru)
}

\title{
A simulation of the helium diffusion in uranium dioxide crystals: a comparison of the interaction potentials
}

\begin{abstract}
The article studies interaction of radiogenic gases, such as helium with oxide nuclear fuel. The problem of molecular-dynamic modeling of the processes of helium accumulation and diffusion in uranium dioxide crystals is considered. The simulations are carried out taking into account the high energy of the particles (up to $100 \mathrm{keV}$ ), characteristic of cascade collisions. The potentials of interaction of helium atoms with oxygen and uranium ions are proposed, applicable in the range from the energy of thermal motion to hundreds of keV. The well-known potentials of helium interaction in $\mathrm{UO}_{2}$ crystal (R.W. Grimes [1], E. Yakub [2]) are compared with these proposed in this paper. Using molecular dynamics, the coefficients of helium interstitial diffusion are calculated for the temperatures from $1500 \mathrm{~K}$ to the melting point, the values from $1 \cdot 10-4$ to $1 \cdot 10-7 \mathrm{~cm}^{2} / \mathrm{s}$ are obtained. The corresponding activation energies varied from 2 to $2.7 \mathrm{eV}$, depending on the interaction potentials. The results are compared with the experimental data and molecular dynamics calculationsof other authors. The calculated values of the diffusion coefficient are shown to be close to the experimental data on helium interstitial diffusion for the fluorite crystal considered as a structural analogue of the oxide fuel.
\end{abstract}

Keywords: the oxide nuclear fuel, the potentials of interaction, the diffusion coefficient.

\section{Introduction}

The study of the processes of accumulation and diffusion of radiogenic helium in the oxide fuel of nuclear reactors is of practical interest in connection with the existence of such phenomena as swelling and helium embrittlement of reactor materials. Helium bubbles that arise in the volume of fuel crystals can be exposed to cascade collisions that arise as a consequence of nuclear reactions (and neutron irradiation). The computational modeling of the interaction of helium bubbles with collision cascades (high-energy particles from such cascades) in $\mathrm{UO}_{2}$ and $\mathrm{PuO}_{2}$ by molecular dynamics (MD) is actual.

The interaction potentials that are applicable for MD simulation of high-energy interactions in crystals should be correct in a wide range of interparticle distances from $\sim 0.01 \mathrm{eVup}$ to several electron volts. For helium in $\mathrm{UO}_{2}$ and $\mathrm{PuO}_{2}$ crystals, there are no generally accepted potentials of this type. Potentials calculated by the embedded cluster approach in [1] were presented in the Lennard-Jones form. This representation is correct only on the average distances between the helium atom and the nearest ions, which are characteristic for thermal lattice vibrations (Fig. 1). In [2], the He-U and He-O potentials were constructed using the combination rules [3] as the geometric mean potential He-He, U-U and O-O [4]. In this case, the empirical potentials U-U and O-O [4] were used, reconstructed on the basis of the mechanical properties of $\mathrm{UO}_{2}$ at the standard pressure and temperature. Thus, the potentials [2] were also unlikely to describe high-energy collisions.

\section{The pair interaction potentials and the simulation results}

In the present paper, the He-uranium and He-oxygen potentials calculated by the Dmol method [5] in [6] were proposed to simulate high-energy interactions of helium with ions in uranium dioxide. These potentials for calculations were approximated by the «two exponents» function

$$
U_{i j}\left(r_{i j}\right)=\varepsilon \cdot\left(e^{-2 \beta\left(R-R_{m}\right)}-2 \cdot e^{-\beta\left(R-R_{m}\right)}\right) .
$$

The choice of potentials [6] was discussed in [7]. We only note that, in the absence of a better option, the calculated potential of the isoelectronic pair $\mathrm{He}-\mathrm{Gd}^{3+}$ was taken as the $\mathrm{He}-\mathrm{U}$ potential. Below, we refer to these potentials as Potentials I. To increase the range of applicability, the potentials I were extrapolated [7] to the distances less than $0.5 \AA$ by the screening functions [8]. These functions describe the Coulomb interaction of nuclei shielded by the internal electrons. The resulting Potentials II were obtained in the form 


$$
U_{i j}\left(r_{i j}\right)=\frac{A_{1}, i j b^{-B_{1, j} r_{i j}}+A_{2}, i j b^{-B_{2, j} r_{i j}}+A_{3}, i j b^{-B_{3, j} r_{i j}}}{r_{i j}} .
$$

Potentials I and II are shown in Figures 1 and 2, their parameters are given in Table.
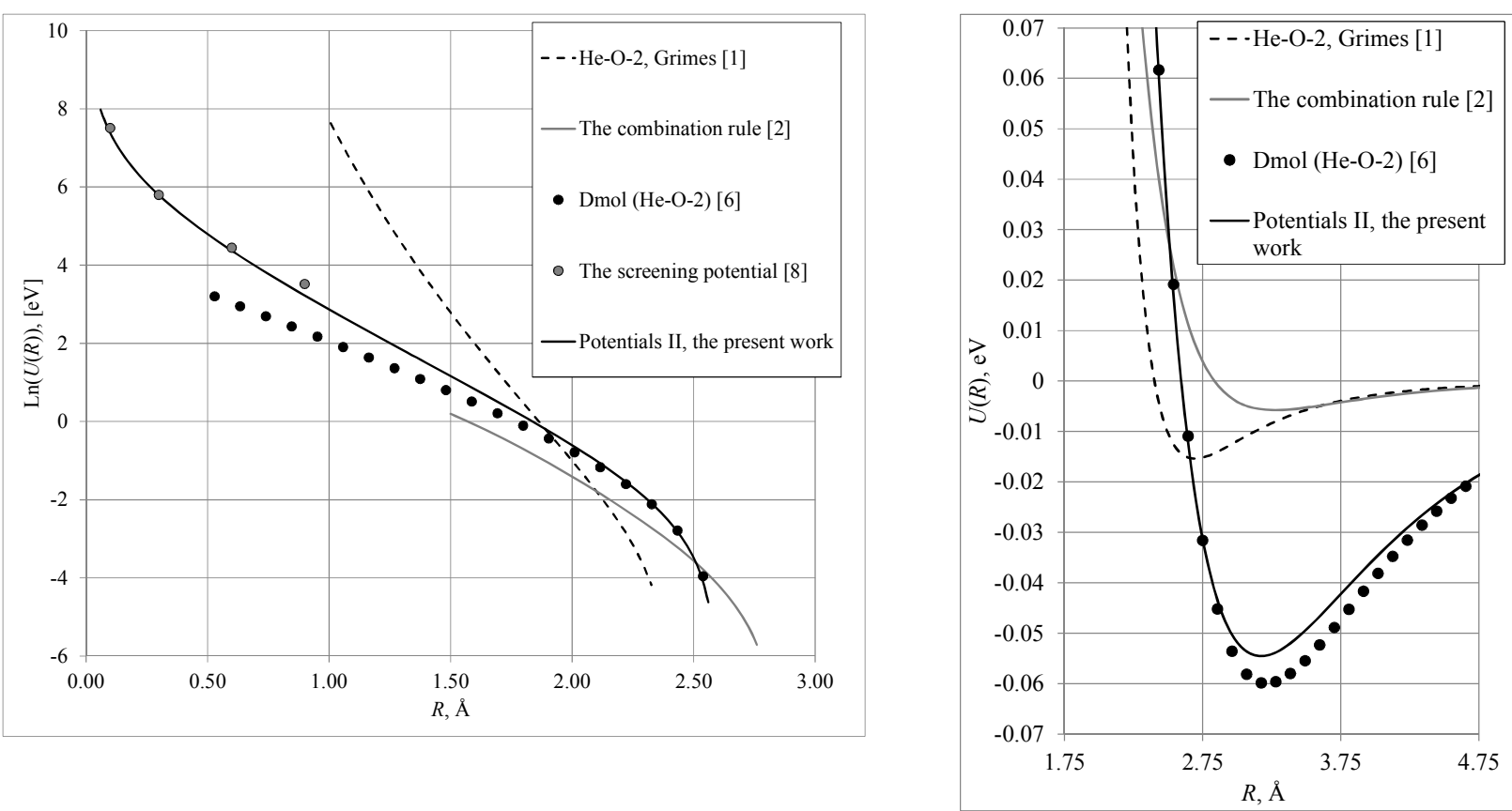

Figure 1. The interaction potentials of helium atoms with oxygen ions in the uranium dioxide crystals. The potential Dmol $\left(\mathrm{He}^{-} \mathrm{O}^{-2}\right)[6]$ in the Figure belongs to the Potentials I set of this work
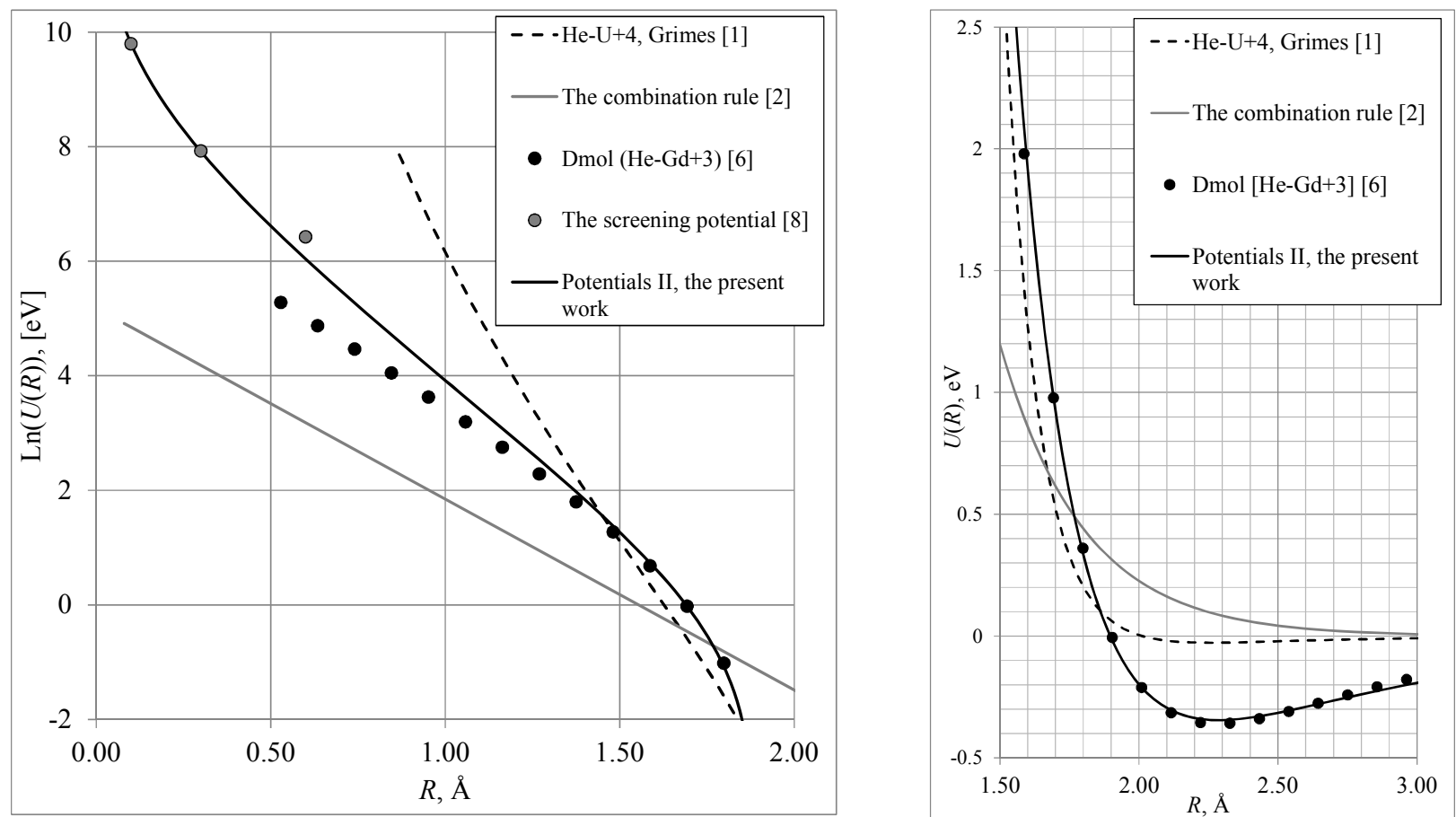

Figure 2. The interaction potentials of helium atoms with uranium and isoelectronic ions. The potential Dmol $\left(\mathrm{He}_{-} \mathrm{Gd}^{+3}\right)[6]$ in the Figure belongs to the Potentials I set of this work 
The parameters of the helium interaction potentials in the $\mathrm{UO}_{2}$ crystal

\begin{tabular}{|c|c|c|c|c|c|c|}
\hline \multicolumn{7}{|c|}{ The Potentials I «two exponents» } \\
\hline Pair & \multicolumn{2}{|c|}{$\varepsilon, \mathrm{eV}$} & \multicolumn{2}{|c|}{$\beta, \AA^{-1}$} & \multicolumn{2}{|c|}{$\mathrm{R}_{\mathrm{m}}, \AA$} \\
\hline $\mathrm{He}-\mathrm{O}^{2-}$ & \multicolumn{2}{|c|}{0.06} & \multicolumn{2}{|c|}{1.14} & \multicolumn{2}{|c|}{3.21} \\
\hline $\mathrm{He}-\mathrm{U}^{4+}$ & \multicolumn{2}{|c|}{0.36} & \multicolumn{2}{|c|}{1.82} & \multicolumn{2}{|c|}{2.28} \\
\hline \multicolumn{7}{|c|}{ The Potentials II, equation (2) } \\
\hline$\Phi *(r)$ & $\mathrm{A}_{1}, \mathrm{eV}$ & $\mathrm{B}_{1}, \AA^{-1}$ & $\mathrm{~A}_{2}, \ni \mathrm{B}$ & $\mathrm{B}_{2}, \AA^{-1}$ & $\mathrm{~A}_{3}$, эB & $\mathrm{B}_{3}, \AA^{-1}$ \\
\hline $\mathrm{He}-\mathrm{O}^{2-}$ & 205.609 & 2.38802 & -2.39227 & 0.70172 & -0.25842 & 0.80359 \\
\hline $\mathrm{He}-\mathrm{U}^{4+}$ & 2655.61 & 3.89292 & -9.69049 & 0.94779 & -0.06768 & 0.22145 \\
\hline
\end{tabular}

In the present work, we compare the known potentials of helium interaction with the environment in the $\mathrm{UO}_{2}$ crystal using the MD calculation of the coefficient of interstitial diffusion of helium. The results of the simulation are shown in Figure 3.

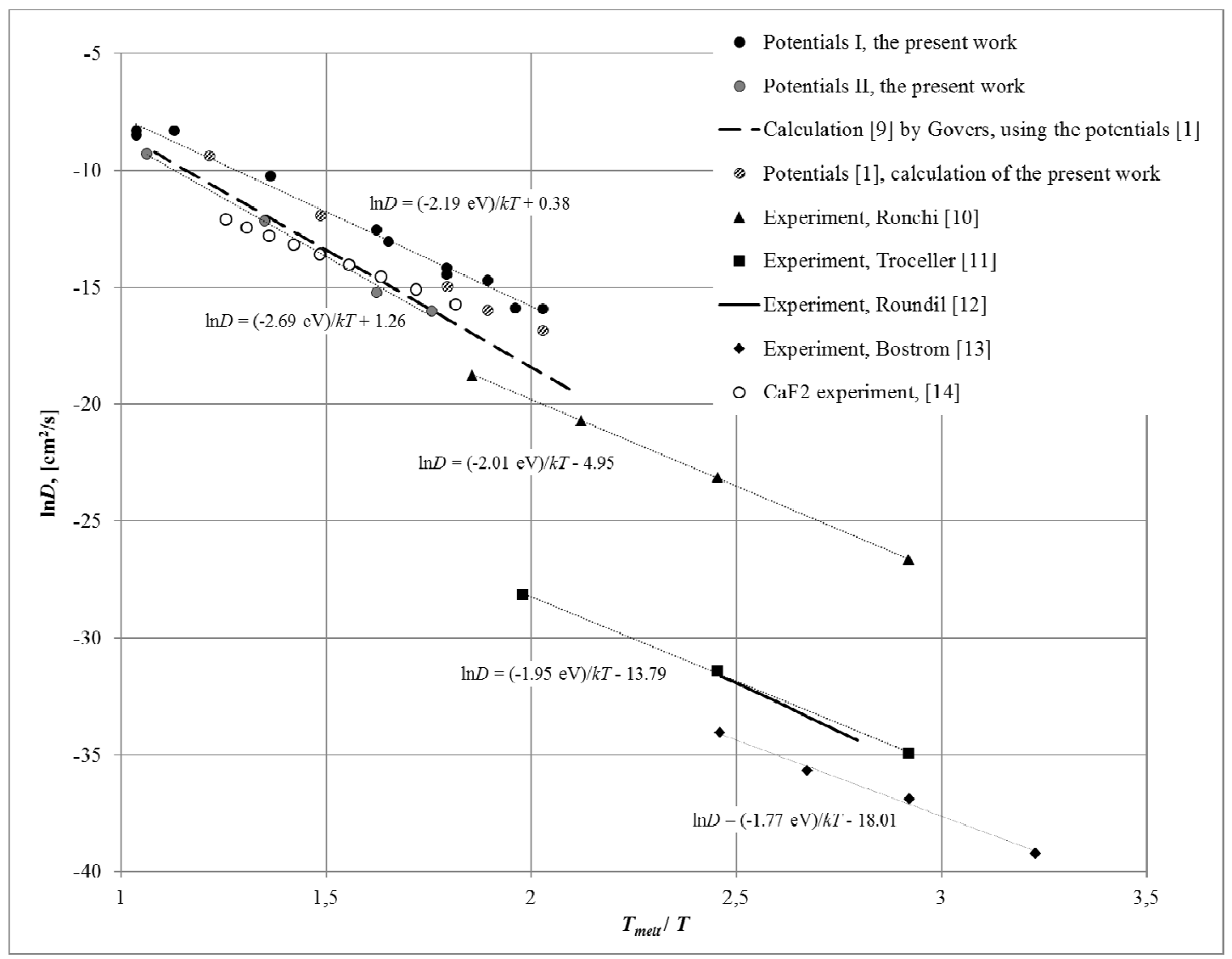

Figure 3. Comparison of the He diffusion coefficients in the $\mathrm{UO}_{2}$

\section{Conclusions}

The following conclusions can be drawn from the results:

1. All the calculated diffusion coefficients at temperatures above $1500 \mathrm{~K}\left(T_{\text {melt }} / T<2\right)$ have values in the range $1 \cdot 10^{-4} \div 1 \cdot 10^{-7} \mathrm{~cm}^{2} / \mathrm{s}$ with the activation energies from 2 to $2.7 \mathrm{eV}$.

2. For the potentials $[1,2]$ and Potentials I of this work, similar dependences of the coefficient of interstitial diffusion on temperature were obtained, while Potentials II gave somewhat higher activation energy.

3. The potentials I and II differed only at distances less than $1.5 \AA$. The divergence of the diffusion activation energy for these potentials shows that it is necessary to refine the potentials of the interaction of helium with oxygen and uranium ions at these distances.

4. Experimental data are characterized by the diffusion activation energies of the order of $2 \mathrm{eV}$, which coincide with the results of calculations in the present and previous works [2, 9]. However, the possibility 
of direct comparison of these results with experiment is doubtful, since the experimental diffusion mechanism could differ from the interstitial mechanism, as indicated by the following considerations:

4.1. The values of the diffusion coefficient measured in [10-13] differ very much, in spite of the similar activation energies. This behavior can be explained assuming that the helium migration process was assisted by some defects and the concentration of these defects in the $\mathrm{UO}_{2}$ samples from [10-13] differed.

4.2. The experimental values of the helium diffusion coefficient in $\mathrm{UO}_{2}$ are underestimated with respect to the characteristic values for the interstitial diffusion. For comparison, Figure 3 shows the $\ln \left(\mathrm{D}_{\mathrm{He}}\right)$ vs. $\left(T_{\text {melt }} / T\right)$ dependence for the interstitial diffusion of helium in $\mathrm{CaF}_{2}$ [14]. The $\mathrm{CaF}_{2}$ crystal is a structural ana$\log$ of uranium dioxide with a very close lattice constant (at room temperature $a_{\mathrm{CaF} 2}=5.46 \AA, a_{\mathrm{UO} 2}=5.47 \AA$ ). It can be seen that the diffusion coefficients of helium in $\mathrm{CaF}_{2}$ are close to the results of simulationof the interstitial migration of $\mathrm{He}$ in $\mathrm{UO}_{2}$ in the present and previous works. On the other hand, the experimental data for $\mathrm{CaF}_{2}$ and $\mathrm{UO}_{2}$ differ by several orders of magnitude, which points to different mechanisms of migration.

\section{Acknowledgments}

The study was carried out with the financial support of the Russian Foundation for Basic Research (RFBR) in the framework of the research project No. 16-52-48008.

\section{References}

1 Grimes R.W. The behaviour of helium in $\mathrm{UO}_{2}$ Solution and migration energies / R.W. Grimes, R.H. Miller, C.R.A. Catlow // Journal of Nuclear Materials. — 1990. — No. 172. — P. 123-125.

2 Yakub E. Diffusion of helium in non-stoichiometric uranium dioxide / E. Yakub, C. Ronchi, D. Staicu // Journal of Nuclear. Materials. - 2010. - No. 400 (3). - P. 189-195.

3 Abrahamson A.A. Repulsive interaction potentials between rare-gas atoms. Heteronuclear two-center systems / A.A. Abrahamson // Physical Review - 1964. — Vol. 133A. - P. 990.

4 Basak C.B. Classical molecular dynamics simulation of UO2 to predict thermophysical properties / C.B. Basak, A.K. Sengupta, H.S. Kamath // Journal of Alloys and Compounds. - 2003. - No. 360. - P. 210.

5 Delley B. An all-electron numerical method for solving the local density functional for polyatomic molecules / B. Delley // Journal of Chemical Physics. - 1990. - No. 92 (1). - P. 508-517.

6 Kupryazhkin A.Ya., Nekrassov K.A., Ryzhkov M.V., Delley B. Determination of potentials of interaction between rare gases and multiply charged ions in Rarefied Gas Dynamics: $23^{\text {rd }}$ International Symposium. — Canada, 2002.

7 Seitov D., Nekrasov K. The potentials of helium-neighbourhood interaction in the crystals of the oxide nuclear fuel for simulation of the high-energy collisions // Youth. Science. Technology (MNTK-2017): collection of scientific works. International scientific-technical conference of students and young scientists in 4 parts-Industrial electronics. Energy 2017. — P. 4: (pp. 48-54). Novosibirsk: Izdatelstvo NGTU.

8 Ziegler J.F. The Stopping and Range of Ions in Solids / J.F. Ziegler, J.P. Biersack, U. Littmark. — New York: Pergamon Press, 1984.

9 Goversa K. Molecular dynamics simulation of helium and oxygen diffusion in $\mathrm{UO}_{2 \pm x} /$ K. Goversa, S. Lemehov, M. Hou, M. Verwerft // Journal of Nuclear Materials. — 2009. - No. 395. - P. 131-139.

10 Ronchi C. Helium diffusion in uranium and plutonium oxides / C. Ronchi, J.P. Hiernaut // Journal of Nuclear Materials. 2004. - No. 325. - P. 1-12.

11 Trocellier P. Application of nuclear reaction geometry for ${ }^{3} \mathrm{He}$ depth profiling in nuclear ceramics / P. Trocellier, D. Gosset, D. Simeone, J.M. Costantini, X. Deschanels, D. Roudil, Y. Serruys, R. Grynszpane, S. Saudé // Nuclear Instruments and Methods in Physics Research, M. Beauvy. — 2003. - B 206. - P. 1077-1082.

12 Roudil D. Helium thermal diffusion in a uranium dioxide matrix / D. Roudil, X. Deschanels, P. Trocellier, C. Jegou, S. Peuget, J. Bart // Journal of Nuclear Materials. - 2004. - No. 325. - P. 148-158.

13 Bostrom W.A. Effects of Irradiation on Bulk Uranium Dioxide. U.S. / W.A. Bostrom, J.D. Eichenberg, P.W. Frank, T.J. Kisiel, B. Lustman, K.H. Vogel // Atomic Energy Commission Report WAPD-183 (unpublished). — 1957.

14 Kupryazhkin A.Ya. Interstitial diffusion of helium in fluorides of calcium, strontium, barium / A.Ya. Kupryazhkin, Ye.V. Popov // Solid state physics. — 1984. — Vol. 26. - No. 1. 


\title{
Д.Д. Сеитов, К.А. Некрасов, А.Я. Купряжкин, С.К. Гупта, А.Т. Ақылбеков \\ Уран диоксиді кристалдарында гелий диффузиясын модельдеу: әсерлесу потенциалдарын салыстыру
}

\begin{abstract}
Мақала гелий сияқты радиогенді газдың оксидті ядролық отынмен әрекеттестігін зерттеуге арналған. Молекулалық-динамикалық модельдеу арқылы ядролық отын $\left(\mathrm{UO}_{2}\right)$ оксидінің кристалдарында гелийдің диффузиясы және тасымалының үдерісі қарастырылды. Модельдеу соқтығысу каскадтарына тән жоғары энергиялы бөлшектерді ескере отырып (100 кэВ дейін) жүзеге асты. Жылу қозғалысы энергиясынан бастап, жүздеген кэВ диапазонында қолданылатын гелий атомдарырының оттегі, уран, плутоний иондарымен әсерлесу потенциалдары ұсынылды. Авторлармен ұсынылған әсерлесу потенциалдарымен кеңінен танымал гелий мен $\mathrm{UO}_{2}$ кристалы ортасының әсерлесу потенциалдары (R.W. Grimes et al. [1], E. Yakub et al. [2]) арасында салыстыру жүргізілді. Молекулалық-динамикалық әдіспен гелийдің интерстициалды диффузия коэффициенті $1500 \mathrm{~K}$ бастап балқу температурасына дейін есептелінді, анықталған өлшемдер 1·10-4 және 1·10-7 $\mathrm{cm}^{2} / \mathrm{c}$ аралығында жатыр. Диффузияның белсенді энергиясы әсерлесу потенциалдарын таңдалуына байланысты 2-ден 2,7 эВ-ге дейін ауытқиды. Алынған нәтижелер эксперименттік деректермен, сондай-ақ басқа да авторлардың молекулалық-динамикалық әдісін колдана отырып алынған есептеулермен салыстырылды. Атап айтқанда, есептелген диффузия коэффициентінің мәндері ядролық оксидті отынның құрылымдық аналогы - флюорит кристалындағы гелийдің интерстициалды диффузиясының эксперименттік деректерімен сәйкеседі.
\end{abstract}

Кілт сөздер: молекулалық-динамикалық модельдеу, оксидті ядролық отын, әсерлесу потенциалдары, диффузия коэффициенті.

\section{Д.Д. Сеитов, К.А. Некрасов, А.Я Купряжкин, С.К. Гупта, А.Т. Акылбеков \\ Моделирование диффузии гелия в кристаллах диоксида урана: сопоставление потенциалов взаимодействия}

\begin{abstract}
Статья посвящена исследованию взаимодействия радиогенных газов, таких как гелий, с оксидным ядерным топливом. Рассмотрена задача молекулярно-динамического моделирования процессов накопления и диффузии гелия в кристаллах диоксида урана. Моделирование проводилось с учетом высоких энергий частиц (до 100 кэВ), характерных для каскадов столкновений. Предложены потенциалы взаимодействия атомов гелия с ионами кислорода, урана, применимые в диапазоне от энергии теплового движения до сотен кэВ. Проведено сопоставление широко известных потенциалов взаимодействия гелия с окружением в кристалле $\mathrm{UO}_{2}$ (R.W. Grimes et al. [1], E. Yakub et al. [2]) с потенциалами, предложенными в настоящей работе. Методом молекулярной динамики рассчитаны коэффициенты междоузельной диффузии гелия в диапазоне температур от $1500 \mathrm{~K}$ до плавления. Полученные значения лежат в диапазоне от $1 \cdot 10-4$ до $1 \cdot 10-7 \mathrm{~cm}^{2} / \mathrm{c}$. Соответствующие энергии активации диффузии варьировались от 2 до 2.7 эВ, в зависимости от выбора потенциалов взаимодействия. Полученные результаты сопоставлены с экспериментальными данными, а также молекулярно-динамическими расчётами других авторов. В частности, показано, что значения коэффициента диффузии, рассчитанные в работе, близки к экспериментальным данным по междоузельной диффузии гелия для структурного аналога ядерного оксидного топлива — кристалла флюорита.
\end{abstract}

Ключевые слова: молекулярно-динамическое моделирование, оксидное ядерное топливо, потенциалы взаимодействия, коэффициент диффузии. 